\title{
Earnings Management through Real Activities and Its Impact on Future Operating Performance
}

\author{
Earnings Management through Real Activities and its Impact on Future Operating Performance \\ Lina Rahmawati ${ }^{\# 1}$, Iman Harymawan ${ }^{\# 2}$, Agus Widodo Mardijuwono ${ }^{\# 3}$ \\ \#Airlangga University, INDONESIA \\ 2harymawan.imanefeb.unair.ac.id
}

\begin{abstract}
This study examines the effect of earnings management through real activities on future operating performance. This study uses data of firms listed in Indonesia Stock Exchange in the period of 2012 to 2013. The analysis technique employed in this study is multiple linear regression analysis and processed using STATA / MP 14.2. The results show that real activities on earnings management has positive and significant association with future operating performance. This finding indicates that the earnings management through real activity has occurred on production costs and operating cash flows as a signal that company will have better future operating performance.
\end{abstract}

Keywords — Real Earnings Management, Future Operating Performance

\section{INTRODUCTION}

Ever since the ASEAN Economic Community (AEC) agreement applied into force which further develop the investment in Indonesia, less boundaries and bigger opportunities emerge. This resulted in a business competition becomes increasingly fierce. Business operators trying to present good financial statements for the purpose of attracting investors. One way to polish financial statements is by doing earnings management.

Earnings management can be done in two ways namely the manipulation of accruals and real manipulation. Earnings management through real activities manipulation (real earnings management) are more often used as (1) manipulation of accruals is more often used as the center of observation or inspection by auditors and regulators, (2) focusing attention on accrual manipulation of risky action. This is because real earnings management activity indistinguishable from optimal business decisions and more difficult to detect, even though the costs used is higher when compared with accrual earnings management. The real manipulation can be detected through an abnormal value of the cost of production, the value abnormal discretionary costs, and the value of cash flow abnormal operating activities.

The magnitude of the effect of an abnormal value of the production costs, discretionary costs, and cash flow operating activities, often related to the company's operating performance in the future (future operating performance). For cash flow from operating activities is a reflection of how the results of operations of the company. Furthermore, cash flow from operating activities is a reflection of how the results of operations of the company because it largely comes from repetitive activities undertaken by the company continuously, then the operating cash flow at this time can be a predictor for future operating performance (future operating performance)

Research conducted by [12] proves that real earnings management does not affect the course of future operating performance but the real earnings management which is used to achieve the profit target that will affect the future operating performance significantly and positively.

Research conducted by [15] shows that companies carrying management of real profit by means of: (1) offer rebates to increase sales, (2) conduct an excessive production to reduce the cost of goods sold (COGS), (3) reducing discretionary spending to increase its profit.

Research conducted by [10] indicates that the correlation between real earnings management and future cash flows is insignificant. In addition, the real earnings management activities economically significantly degrade the performance of the company's operations. 
Based on the background described above, then the problems will be examined in this study are as follows: 1. Is the real earnings management through manipulation of the production costs affect the future operating performance? 2. Is the real earnings management through manipulation of discretionary costs affect the future operating performance? 3. Is the real earnings management through manipulation of the cash flow operating activities affect the future operating performance?

\section{THEORETICAL AND DEVELOPMENT OF HYPOTHESES}

\section{THEORETICAL}

\section{A. Agency Theory}

Agency theory explains the relationship between the owners of capital (principal) as the investor to the manager (agent). Investors delegate their role to manage the business to agents (managers) in running the firm. However, the contractual relationship between the owner (principal) and the manager (agent) may not come into real-world practices due to conflict of interest or what known as information asymmetry. The state of information asymmetry occurs when unequal distribution of information between principal and agent take place. As a result of information that is not balanced (asymmetrical information), it is much harder for principal to monitor and control the actions of the agent.

According to [18]), there are two kinds of asymmetric information (information asymmetry), namely: Adverse selection, where managers and other people in, usually know more about the state and prospects of the company compared to investors as outsiders. Moral hazard, namely that the activities carried out by a manager is not entirely known by shareholders and lenders, so that managers can perform actions outside the knowledge of shareholders. Such measures may include breach of contract and ethics or norms may not be worth doing.

\section{Hypothesis Development}

Effect of Real Earnings Management Through Manipulation of Production Costs Againts

\section{Future Operating Performance}

In [15], it is explained that the method for firms to engage in abnormal level of production is by having overproduction. The manager of the firm can produce more goods than what is demanded to exceed the expected demand which intended to boast business profit. With higher production, fixed overhead costs can be allocated to a larger number of units so that the fixed costs per unit will be lower. Along the reduction in fixed costs per unit is not offset by an increase in the marginal costs, yielding lower total costs per unit. It would indicate lower cost of goods which increases the firm's margin. Although the company decide to overproduce on merchandise, it will incur retained costs which is not recoverable in the period of sales. As a result, cash flow from operating activities is lower than normal sales level. Based on the explanation then the hypothesis is:

H1: Real earnings management through manipulation of the production costs affect the future operating performance

\section{Effect of Real Earnings Management Through Manipulation Cost of Discretionary Against Future Operating Performance}

Roychowdhury [15] suggests that one method employed in engaging into real earning management activity is through reduction of discretionary cost, in which firms arbitrarily reduce discretionary fees charge on the same period with the costs incurred. Reduction of costs which are reported, is intended to increase profits so that the target set can be attained. This method is usually done when the costs are not generating revenue and profits immediately. Based on the explanation then the hypothesis is:

$\mathrm{H} 2$ : Real earnings management through manipulation of the cost of discretionary affect the future operating performance

\section{Effect of Real Earnings Management Through Manipulation of Cash Flows Operating Activities Against Future Operating Performance}

Cash flows from operating activities may be used to determine whether the operations of the company to generate cash flow sufficient to repay short-term loans, maintaining the company's operational 
capabilities and to finance expenditures on operational activities. Cash flows operating activities contain details of the amount of cash receipts and disbursements of the company's operational activities. In [15] it is described that the method employed in order to polish financial statement is by having sales management to exceed abnormal targets. Sales management is used as a means to temporarily increase sales in the current year to increase earnings in the achievement of targeted profits. Furthermore, actions taken to accelerate this method is to accelerate the acquisition of additional sales through price cut and credit that are higher. The increase in sales volume for their rebates or discounts may not be the case when the company re-establishes the old price. Increased sales volumes led to higher current year profit but cash flow declined due to smaller cash inflow due to the sale of loans and rebates, therefore, sales management activities led to cash flow operating activities decreased the current period compared to normal sales levels. The explanation is based on the hypothesis is:

H3: Real earnings management through manipulation of cash flows operating activities affect future operating performance

\section{RESEARCH METHODOLOGY}

This research is quantitative descriptive research using associative method. The objective of the research is to determine the correlation or causal relationship among variables. Associative research is research that aims to determine the relationship between two variables or more (Sugiyono, 2010: 11).

\section{Operational Definition \\ Future Operating Performance}

Operating cash flow is largely derived from nonintermittent activities or continuous activities to generate cash flow taken by the firm, cash flow for the year can be attributed to the next year), so that the operating cash flow at this time can be predictor to the operating performance of the future (future operating performance).

\section{Estimate The Normal Level of Production Cost}

Estimation of normal level of production cost is defined as the effort of management to increase sales on a temporary basis by offering price discounts and soft loans.

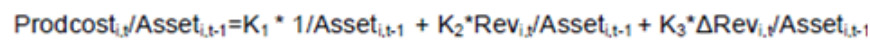

$$
\begin{aligned}
& +K_{4}{ }^{*} \Delta \operatorname{Rev}_{i, s, 1} / \text { Asset }_{i, 1,1}+\varepsilon_{i, t}
\end{aligned}
$$

Where

$$
\text { Prodcosti, } t=\text { COGSi, } t+\Delta \text { Invi, } t
$$

\section{Estimate The Normal Level of Discretionary Expenditures}

Discretionary expenditures that can be reduced include cost of advertising, research and development costs, cost of sales, and general administration costs such as employee training costs and reparation costs. Reduction of the costs at the end of the accounting period will lead to debt account being reduced below normal level which will incur positive abnormal accruals. Thus, companies can reduce cost reported amid revenues remain constant, profit increases.

$\operatorname{DisExp}_{\mathrm{i}, \mathrm{t}} /$ Asset $_{\mathrm{i}, \mathrm{t}-1}=\mathrm{K}_{1}{ }^{*} 1 /$ Asset $_{\mathrm{i}, \mathrm{t}-1}+\mathrm{K}_{2}{ }^{*} \operatorname{Rev}_{\mathrm{i}, \mathrm{t}-1} /$ Asset $_{\mathrm{i}, \mathrm{t}-1}+\varepsilon_{\mathrm{i}, \mathrm{t}}$

\section{Estimate The Normal Level of CFO}

The company produces goods greater than that required with the aim of achieving the expected demand so that profits can be increased. Large scale production led to the fixed overhead costs divided by the number of units of large items so that the average cost per unit and cost of goods sold decreased. The decline in cost of goods sold will have an impact on improving the operating margin. Along the reduction in fixed costs per unit can not be covered by an increase in the marginal cost per unit, the total cost per unit decreases. This causes the reported cost of goods sold is lower and the company may report a better operating margin. Another impact of the decrease in the cost per unit of goods, trigger massive cash flow from operating activities that is lower than normal sales rate.

CFO $_{i} /$ Asset $_{i-1}=K_{1}{ }^{*} 1 /$ Asset $_{i t-1}+K_{2}{ }^{\star} \operatorname{Rev}_{i} /$ Asset $_{i t-1}+K_{3}{ }^{*} \Delta \operatorname{ReV}_{i} / A^{\prime} \operatorname{sset}_{i-1}+\varepsilon_{i t}$ 
TABLE I

VARIABLE DEFINITIONS

\begin{tabular}{|c|c|c|}
\hline Variable & Symbol & Definition \\
\hline $\begin{array}{l}\text { Future operating } \\
\text { performance }\end{array}$ & FUTUREPERF & $\begin{array}{l}\text { Using the formula of } \\
\text { future } \\
\text { according to Heshmating } \\
\text { (2014) }\end{array}$ \\
\hline $\begin{array}{l}\text { Abnormal level of } \\
\text { production costs }\end{array}$ & DUMMP & $\begin{array}{l}\text { Using a dummy } \\
\text { variable, with a value of } \\
1 \text { if above the median } \\
\text { and the value } 0 \text { if under } \\
\text { media }\end{array}$ \\
\hline $\begin{array}{l}\text { Abnormal level of } \\
\text { discretionary } \\
\text { expenditure }\end{array}$ & DUMMD & $\begin{array}{l}\text { Using a dummy } \\
\text { variable, with a value of } \\
1 \text { if above the median } \\
\text { and the value } 0 \text { if below } \\
\text { the median }\end{array}$ \\
\hline $\begin{array}{l}\text { Abnormal level of } \\
\text { cash flow from } \\
\text { operating } \\
\text { activities }\end{array}$ & DUMMC & $\begin{array}{l}\text { Using a dummy } \\
\text { variable, with a value of } \\
1 \text { if above the median } \\
\text { and the value } 0 \text { if below } \\
\text { the median }\end{array}$ \\
\hline $\begin{array}{l}\text { Financial } \\
\text { performance } \\
\text { (ROA) }\end{array}$ & FINPERF & $\mathrm{ROA}=\frac{\text { Earnings After Tax }}{\text { Total Assets }}$ \\
\hline Firm size & SIZE & $\mathrm{FSIZE}=\ln$ (total assets) \\
\hline Growth & GROWTH & GROWTH $=\frac{\text { Sales } \mathrm{t}-\text { Sales } \mathrm{t}-1}{\text { Sales } \mathrm{t}-1}$ \\
\hline
\end{tabular}

\section{Types and Sources of Data}

This research uses quantitative and secondary data in the form of financial statements of firms listed in Indonesia Stock Exchange (BEI) in the period of 2012-2013. Secondary data is obtained through documentation method, which is a search tool through written records and documents of the companies. Furthermore, the data used is obtained from www.sahamok.com and www.idx.co.id .

\section{Data Collection Procedures}

Data collection procedure employed in this research is documentation study by collecting secondary data from www.sahamok.com and www.idx.co.id , aiming for period of study of 2012 - 2013. Based on the data collection procedure, the latest up to date data covers financial statement of firms listed in stock exchange through 2015).

\section{Population and sample Research}

\section{Population}

Population is a generalization of region consisting of the object or subject that has certain qualities and characteristics defined by the researchers to be studied, then drawn the conclusion ([16]). The population in this study is manufacturing firms listed in Indonesia Stock Exchange (IDX) from the period of 2012 to 2013 yielding total number of 206 firms.

\section{Study Sample}

The sample in this research is done by using purposive sampling method, the sampling technique with a certain consideration ([16])

\section{Analysis Techniques}

Data analysis technique used in this research is to test the descriptive statistical analysis, Pearson correlation test, and multiple linear regression analysis. The software used to perform data analysis techniques using STATA program 14.0. Distribution of data in this study is likely to have many outliers. Understanding that data used in this study may have outliers, Winsorized technique is used prior to descriptive statistics analysis.

\section{IV.DATA ANALYSIS AND DISCUSSION}

\section{A. Descriptive Analysis}

The independent variable of this research is real earnings management proxied by abnormal level of production cost, abnormal level of discretionary expenditures and abnormal level of cash flow from operating activities. The dependent variable in this study is future operating performance. Descriptive statistics is used to provide information of variables used in the study pertaining description of average (mean), minimum, maximum, and standard deviation for each proxy of variables. Result of descriptive statistics of this research can be seen in the table below. 
TABLE II

DESCRIPTIVE STATISTICS

\begin{tabular}{|l|c|c|c|c|c|}
\hline & Mean & Median & $\begin{array}{c}\text { Standard } \\
\text { Deviation }\end{array}$ & Min & $\begin{array}{c}\text { Ma } \\
\mathbf{x}\end{array}$ \\
\hline $\begin{array}{l}\text { FUTUR } \\
\text { EPERF }\end{array}$ & -18.555 & -6.227 & 42.809 & -306.65 & $\begin{array}{c}0.16 \\
6\end{array}$ \\
\hline $\begin{array}{l}\text { DUMM } \\
\text { P }\end{array}$ & 0.5 & 0.5 & 0.501 & 0 & 1 \\
\hline $\begin{array}{l}\text { DUMM } \\
\text { D }\end{array}$ & 0.5 & 0.5 & 0.501 & 0 & 1 \\
\hline $\begin{array}{l}\text { DUMM } \\
\text { C }\end{array}$ & 0.5 & 0.5 & 0.501 & 0 & 1 \\
\hline $\begin{array}{l}\text { FINPER } \\
\text { F }\end{array}$ & 0.098 & 0.043 & 0.234 & -0.113 & 1.61 \\
\hline SIZE & 28.193 & 28.046 & 1.666 & 23.87 & $\begin{array}{c}32.0 \\
26\end{array}$ \\
\hline $\begin{array}{l}\text { GROW } \\
\text { TH }\end{array}$ & 0.316 & 0.13 & 1.342 & -0.897 & $\begin{array}{c}9.55 \\
1\end{array}$ \\
\hline
\end{tabular}

Main Results

TABLE III

REGRESSION RESULTS

\begin{tabular}{|c|c|c|c|}
\hline \multirow{3}{*}{ Variabel } & \multirow{3}{*}{$\begin{array}{c}\text { Predicted } \\
\text { Sign }\end{array}$} & \multicolumn{2}{|c|}{ FUTUREPERF } \\
\hline & & $\begin{array}{l}\text { Multiple Linear } \\
\text { Regression }\end{array}$ & $\begin{array}{c}\text { Robust } \\
\text { Regression }\end{array}$ \\
\hline & & -1 & -2 \\
\hline \multirow{2}{*}{ DUMMP } & \multirow{2}{*}{-} & $12,40 * *$ & $12,40 * *$ \\
\hline & & $(2,41)$ & $(2,58)$ \\
\hline \multirow{2}{*}{ DUMMD } & \multirow{2}{*}{ - } & 9,13 & $9,13 *$ \\
\hline & & $(1,23)$ & $(1,92)$ \\
\hline \multirow{2}{*}{ DUMMC } & \multirow{2}{*}{+} & $16,46^{* *}$ & $16,46 * *$ \\
\hline & & $(2,48)$ & $(2,56)$ \\
\hline \multirow{2}{*}{ FINPERF } & \multirow{2}{*}{+} & $-64,56^{*}$ & $-64,56 * * *$ \\
\hline & & $(-2,69)$ & $(-7,51)$ \\
\hline \multirow{2}{*}{ SIZE } & \multirow{2}{*}{+} & $18,19 * * *$ & $18,19 * * *$ \\
\hline & & $(4,83)$ & $(12,71)$ \\
\hline \multirow{2}{*}{ GROWTH } & \multirow{2}{*}{-} & 2,20 & 2,20 \\
\hline & & $(1,52)$ & $(1,49)$ \\
\hline $\begin{array}{l}\text { Year } \\
\text { dummies }\end{array}$ & & Included & Included \\
\hline $\begin{array}{l}\text { Adjusted } \\
\text { R2 }\end{array}$ & & 0,5840 & \\
\hline R-Squared & & 0,5982 & 0,5982 \\
\hline $\mathbf{N}$ & & 206 & 206 \\
\hline
\end{tabular}

Based on the summary of the results of multiple regression analysis above, it shows that the regression coefficient is both positive and negative. Positive coefficient suggests independent and dependent variable change in the same direction, while negative coefficient indicate that independent and dependent variable change in the opposite direction. Substantial contribution from variables as abnormal value of the cost of production, abnormal values of the cost discretionary, and abnormal values of operating cash flow, financial performance (FINPERF), firm size (SIZE), suggest an increase in sales (GROWTH) to future operating performance (FUTUREPERF) at 59, 82\%. While the rest of $40.18 \%$ is explained by other variablesthat are not included in the study. The results are derived from the following research model:

FUTUREPERF $_{i t}=\alpha+\sum_{i=1}^{n} \beta i$ REM $_{i t}+\sum_{i=1}^{n} \beta i$ CONTROLS $_{i t}+\varepsilon_{i t}$

The table above shows the results of regression analysis of earnings management through real activities to future operating performance with variable control. Positive coefficient indicates a unidirectional change among independent variables towards dependent variables, whereas negative coefficient indicates opposite changes of independent variables and dependent variables. Table 1 shows the results of multiple linear regression analysis, while Table 2 shows the results of multiple linear regression analysis using robust.

In table 1 DUMMP variable regression coefficient value of 12.40 has a positive influence on FUTUREPERF. This variable has a $\mathrm{p}$ value of 0.017 indicates that significant at the 5\% level. While in table 2 at 12.40 and has a positive influence on FUTUREPERF. This variable has a $p$ value of 0.011 indicates that significant at the $5 \%$ level.

In table 1 DUMMD variable regression coefficient value of 9.13 and had a positive influence on FUTUREPERF. This variable has a $\mathrm{p}$ value of 0.219 indicates that it is not significant. While in table 2 of 9.13 and has a positive influence on FUTUREPERF. This variable has a $\mathrm{p}$ value of 0.057 indicates that significant at the $10 \%$ level.

In table 1 DUMMC variable regression coefficient value of 16.46 and has a positive influence on FUTUREPERF. This variable has a $\mathrm{p}$ value of 0.014 indicates that significant at the 5\% level. While in table 2 at 16.46 and has a positive 
influence on FUTUREPERF. This variable has a $\mathrm{p}$ value of 0.011 indicates that significant at the $5 \%$ level.

\section{DISCUSSION HYPOTHESIS}

A. Effect of Real Earnings Management Through Manipulation of Production Costs Towards Future Operating Performance

Result showed that real earnings management through manipulation of production costs has significant positive effect on future operating performance. It shows that the variables of abnormal values through production costs occur when firms produce above its normal level. High production level led to fix overhead cost is being spread over a large quantity of production units resulting in lower fixed costs per unit of production. This resulted in a lower reported cost of goods sold and generate higher operating margin ([15]). This study supports the [23] which stated that the company tends to do the real earnings management by producing excessive quantity (overproducing). This is in line with [11] Gunny (2010) which states that the real abnormal activities aim to achieve profit targets which will provide future a betterperformance.

\section{B. Effect of Real Earnings Management Through Manipulation Cost of Discretionary Towards Future Operating Performance}

Result showed that real earnings management through manipulation of discretionary cost has positive and insignificant effect. It showed that companies' deliberate actions of executing discretionary cost minimize cash outflows as well as to reduce debt incurred which in turn has positive effect on operating performance. Therefore, future operating performance will be positive. This is in line with the Taylor \& Xu (2010) which states that the policy of reducing discretionary spending undertaken by the company in order to raise profits do not give a negative impact to the company's performance in the future. As well as by Gunny (2010) which states that the real abnormal activities aim to achieve profit targets which will provide future a betterperformance.

C. Effect of Real Earnings Management Through Manipulation of Cash Flows Operating Activities Against Towards Future Operating Performance
Result showed that real earnings management through manipulation of cash flow has significant positive effect on future operating performance. According to the result, positive value indicates that the net cash flow of firm operating in abnormal activity is lower than firm which operate at normal activity. Companies suspected real earnings management tend to have negative abnormal cash flow ([15]). Due to the lower value because of abnormal operating cash flow, the higher the profit that was in line with Gunny (2010) states that the real abnormal activities aim to achieve profit targets which will provide future a better performance.

VI. CONCLUSIONS, SUGGESTIONS, AND LIMITATIONS

\section{A. Conclusion}

Based on the data analysis and discussion of hypotheses that have been prepared and have been tested in the previous section, it can be summed up as follows:

- The test results and analysis indicate that the value of abnormal production costs affect the future operating performance. The results of this study indicate that abnormal values of production costs have significant positive effect on future operating performance. It indicates that firms, through manipulation of earnings management influence their production costs to arrive at better future operating performance.

- The test results and analysis show that the abnormal discretionary costs affect the future operating performance. The results of this study indicate that abnormal values of discretionary costs have insignificant and positive effect to future operating performance. These results indicate that the company has engaged to earnings management through manipulation of dicretionary expensenditure and operating performance of companies in the future will not increase due to this activity.

- The test results and analysis show that the abnormal value of cash flows from operating activities affect the future operating performance. The results of this study indicate that abnormal values of cash flows from operating activities prove that cash flow has 
significant and positive effect on future operating performance. These results indicate that the company has engaged to earnings management through manipulation of the cash flow from operating activities and will increase the company's operating performance in the future.

\section{B. Suggestions}

- Variables that are not evident in this study should be in future studies using the characteristics of earnings management through real activities of other variables. Which is expected to reflect the variables used, for example, the value of sales.

- Expanding research by using a sample of firms from other industrial sectors.

- The results of this study indicate that real earnings management through manipulation of the activity of operating cash flow effect on future operating performance. So that decision makers can use this as an additional independent variable consideration in decision-making.

\section{Limitations of}

- The data is obtained from www.idx.com so there are some companies that excluded due to incomplete data.

- In this research has not taken into account whether the company conducted additional samples of corporate assets in the study period

\section{REFERENCES}

[1] Agmarina, Meiza and Etna Nur Afri Yuyetta. (2011). Through Real Activities Manipulation Impact of Cash Flows Operating Activities Against Market Performance. P. 3-44.

[2] Anshori, Muslich and Sri Iswati. (2009). Quantitative Research Methodology. Surabaya: Airlangga University Press (AUP).

[3] Armando, Equivalent and A. Farahmita. (2011). Accruals and Earnings Management Through Real Activities Around Additional Share Offer and Its Effect on Corporate Performance: Study on Companies Listed in Indonesia Stock Exchange Year 2001 to 2007. Accounting National Symposium XV, Banjarmasin.

[4] Brigham, Eugene F. And Joel F. Houston, (2006). Basics of Financial Management. Book One, Tenth Edition, Salemba Four: Jakarta.

[5] Chariri and Ghozali, Achmad (2007) Theory of Accounting, Publisher Andi, Yogyakarta

[6] Daniel Cohen A, Aiyesha Dey, and Thomas Z. Lys (2007). Real and Accrual-Based Earnings Management in the Pre- and Post-Sarbanes Oxley Periods. Accounting Review, forthcoming.

[7] Cohen D, Zarowin P, 2010. Acrual-based and real earnings management activities around seasoned equity offerings. Journal of Accounting and Economics 50: 2-19.

[8] Dechow, Kothari and Ross MSP Patricia L. Watts (1998), The Relation Between Earnings and Cash Flows. Journal of Accounting and Economics, 25 (2), pp. 133-168.

[9] Ghozali, Imam, (2013). Applications Multivariate Analysis with IBM SPSS 21. Program 7th Edition, Publisher Diponegoro University, Semarang.

[10] Gunny, K. (2005). What are the Consequences of Real Earnings Management? Working Paper. University of Colorado.

[11] Gunny, K. (2010). The Relation Between Earnings Management Using Real Activities Manipulation and Future Performance: Evidence from MeetingEarnings Benchmarks. Contemporary Accounting Research. Vol. 27. No. 3: 855-888.

[12] Heshmat, Nesa. (2014). Studying the Effect of Real Earnings Management on Future Operating Performance of Manufacturing Companies Accepted in Tehran Stock Exchange (emphasizing suspected at earnings management firm-years). International Journal of Management and Humanity Sciences, Vol. 3 (S), 2082-2091.

[13] Jensen, M. C and Meckling, WH (1976). Theory of the Firm: Managerial Behavior, Agency Costs and Ownership Structure. Journal of Financial Economics, October, 1976, V. 3, No. 4, pp. 305-360. Avalaible from: http://papers.ssrn.com

[14] Nany, Magdalena. (2013). Analysis of Operating Cash Flow Prediction Capability, Journal of Accounting Dynamics. Volume 5 Number 1. Surakarta.

[15] Roychowdhury, Sugata. (2006). Earnings Management through Real Activities Manipulation. Journal of Accounting and Economic, 42, 335-370.

[16] Sugiyono. (2014). Business Research Methods (Quantitative Approach, Qualitative and R \& D). Bandung: Alfabeta.

[17] Sunarto. 2009. Theory and Profit Management Agency. Accounting Studies, Vol I (1: 13-28).

[18] Scott, William R, 2009. Financial Accounting Theory. Fifth Edition Canada Prentice Hall.

[19] Taylor, GK \& RZ Xu. (2010). Consequences of Real Earnings Management on Subsequent Operating Performance. Research in Accounting Regulation,128-132.

[20] Thomas, JK and Zhang, H. (2002). "Inventory Changes and Future Return." Review of Accounting Studies. 7: 163 - 187.

[21] www.sahamoke.com

[22] www.idx.co.id

[23] Zang, LM (2006). Evidence on The Tradeoff Between Accrual Real Manipulation and Manipulation. Working paper.Duke University.

[24] Zhao, Yijiang. (2012). Protection Take over and managerial Myopia: Evidence from Real Earnings Management. Avalaible from: http://papers.ssrn.com 